\title{
ADAPTIVE MECHANISMS OF RECOVERY FROM LATE RADIATION INJURIES USING DRUG AND REFLEXO-LASER THERAPY
}

\author{
E. Kuzmina*, A. Degtyareva, T. Mushkarina, S. Zatsarenko
}

\author{
A.F. Tsyb Medical Radiological Research Center - Branch of the National Medical Research Center of Radiology \\ of the Ministry of Health of the Russian Federation, Obninsk, Russia
}

\begin{abstract}
We examined 240 patients (with late radiation-induced injuries to the skin, underlying soft tissues and internal organs) who had undergone radiotherapy or combination therapy for breast cancer, cervical cancer, uterine body cancer and Hodgkin's lymphoma at different times. Therapy for radiation-induced injuries developed and being performed at MRRC with the use of pharmacological agents (analgetics, neuroleptics and narcotics), so-called basis therapy, in combination with reflexotherapy may considerably reduce psycho-emotional and pain symptoms of late radiation-induced injuries. The analgesic effect is achieved after the first 3-5 sessions of therapy including reflexolaser treatment. As a result, the use of analgesics and narcotics can be reduced. This therapy improves the quality of life for patients: they can attend to themselves and add more physical activity to their life. The effects of basis therapy alone (5o patients) and in combination with reflex treatment (46 patients) on immunity were compared. Immunity data of 70 practically healthy people made up the control group. It restores adaptation mechanisms while reducing immune hyperactivation and immunodepression. By adding reflexo-laser treatment, basis therapy appeared more successful restoring immunological disorders.
\end{abstract}

Keywords: Immunity, late secondary radiation-induced injuries, medication therapy, reflexo-laser therapy

\section{INTRODUCTION}

Late radiation-induced injuries to the skin and underlying soft tissues often occur after combination therapy and radiotherapy for cancer as secondary vascular and neurological disorders [1]. In such cases, there is usually evidence of secondary immunodeficiency induced by radiation and microbial contamination. Current methods of restoration of radiation-induced injuries include medication therapy such as analgesics, neuroleptics and narcotics [1]. Therefore, the search for effective non-pharmacological restoration methods still remains a relevant and pivotal challenge. Reflexotherapy (acupuncture), as a method of treatment by influencing on human body points, successfully use in medical practice for more thousand years. The World Health Organization recognizes the effectiveness of acupuncture in the treatment of a wide range of diseases. Acupuncture mechanisms are not fully understood and now actively studied [2]-[6]. Numerous experimental and clinical research studies gave the possibility to identify the peripheral [7]-[9], segmental [9]-[11]: and central levels [12]-[16] of acupuncture effects. The neuroamine link of the acupuncture mechanism connects the immune, nervous and endocrine systems, whose coordinated work supports homeostasis and vital activity of the body [4]. Acupuncture protects against the destruction of genes that occur with age by changing the transcription of genes responsible for the aging process. Therefore, acupuncture is an invariable component of anti-aging programs [16].

The purpose of this study is to substantiate the possibility of restoring late radiation-induced injuries to the skin and underlying tissues by combination therapy including reflexo-laser treatment. To achieve this purpose, the following tasks were solved:

1. Clinical efficiency of some restoration measures including reflexo-laser therapy was evaluated;

2. Efficiency of immunity correction following basis drug therapy and its combination with reflex therapy was determined.

Study design: a single-center, single-stage, cohort, open, controlled study was conducted with a retrospective analysis of the data of patients with radiation injuries that developed over the long term after cancer treatment.

\section{MATERIALS AND METHODS}

\subsection{Characteristics of patients}

We examined 240 patients with late radiationinduced injuries. They were undergone radiation or combination therapy 2-20 years ago. For combination

\footnotetext{
*kuzmina e g@mail.ru
} 
radiotherapy of breast cancer, a total tumor dose of 46$50 G y$ was given. For combination (intracavitary + remote) radiotherapy of cervical cancer, a total tumor dose of 70-80Gy was given. For treating uterine body cancer, radiation therapy with a total tumor dose of 75$85 \mathrm{~Gy}$ was combined with surgery. For chemoradiotherapy of Hodgkin's disease, a consolidation radiation dose of 24-30Gy was administered.

In general, body health and well-being of patients were usually assessed by their physical, emotional and spiritual state.

In all patients, late radiation and combined-therapy injuries to the skin, soft tissues and internal organs were identified inside irradiation and operative fields. Clinically, they manifested themselves as plexitis, neuritis, neuralgias (along with secondary radiationinduced edemas of the extremities and pain syndrome with different severity grades) as well as radiationinduced proctitis and cystitis.

Pain intensity was assessed using a digital rating (numerical rank) pain scale, NRS (17). The intensity of pain was characterized by a moderate or severe degree in most patients. A zero value means a complete absence of discomfort, a value between 1 and 2 means a mild pain that does not interfere with daily life. When an individual can still work but less effectively because of unpleasant physical sensations, the degree of pain ranges between 3 and 4. A value between 5 and 6 means a moderately strong pain that interferes with normal daily activities. There is difficulty concentrating. A value between 7 and 8 is considered a severe pain that significantly limits patient's ability to eat, sleep and sometimes breathe as well as to perform normal daily activities or maintain social relationships. Conversing requires great effort. A value between 9 and 10 means excruciating or unspeakable pain. The patients are bedridden and possibly delirious.

Sleep quality, depressive symptoms and self-esteem were determined by the Burns Depression Checklist [18].

\subsection{Restoration methods}

240 patients underwent basic drug therapy followed by reflex laser exposure to reflex zones (basis + reflexolaser therapy).

Basis medical treatment of late radiation injuries that occurred 2-20 years after specific (radiation or combination) cancer therapy was carried out using conventional drug therapy with vascular, antiinflammatory, antimicrobial agents, analgesics and topical preparations $(10-15 \%$ dimethyl sulfoxide solution) administered to areas of late radiation injuries. Acupuncture points were prescribed basing on principles of the symptomatic treatment taking into account patients' individual characteristics. The reflex zone is an area of zonal therapy that interacts with all parts of the body. The pressure exerted on this area helps a certain organ or a certain part of the body to relieve pain and symptoms of the disease. To perform acupuncture, the classical method of corporal and auricular points was used [19]. Treatment consisted of 10-12 sessions.

When the upper extremities were injured, the following corporal points were used: GI11; GI10; TR5; P9,7; T14; GI22; GI23; GI4; GI2; IG3; IG11; E36; V6o.
The auricular acupuncture points treated were: Shen Men, points of the occiput, cerebral cortex, cervical spine, arm, hand, elbow (at the injury level). When the lower extremities were injured, the following corporal points were used: E36; E41; V6o, V62, Rp6, Rp4, VB39. The auricular acupuncture points treated were: Shen Men, points of the cerebral cortex, occiput, kidney, lumbosacral spine, femur, knee, shin, foot. Treatment started with corporal and auricular acupuncture. After acupuncture needles were removed, laser therapy was performed using the UZOR semiconductor laser apparatus with wavelength of 0.89 microns, impulse frequency of $1600-3000 \mathrm{~Hz}$, maximum power of $2.1 \mathrm{~W}$, for 5 minutes daily to the site of radiation damage [5].

The health status was assessed before and after the course of restoration therapy.

\subsection{Methods of estimation of the immune status}

The immune status was investigated before starting and after the end of restoration therapy in 96 patients with late radiation injuries aggravated by a marked pain syndrome and torpid course. The number of leukocytes and lymphocytes in the immune system was determined. The lymphocyte population structure was investigated by flow cytometry (FACScan and FACSCanto II, firm Becton Dickinson) using monoclonal antibodies, such as the Leu and Becton Dickinson series. Furthermore, total T-lymphocytes; CD3+; T-helper, CD3+CD4+; T-cytotoxic, CD3+CD8+; immunoregulatory index (IRI), i.e. ratio of CD4+/CD8+; B-cells, CD19+CD3-; NKT-cells, $\mathrm{CD} 3+\mathrm{CD} 16+56+$; and NK-cells, CD16+56+CD3-. T-cell activation was estimated by the expression of major histocompatibility complex class II antigen, CD3+HLADR+, and reaction of blast lymphocytes transformation that was spontaneous, induced by phytohemagglutinin, PHA, and stimulation index. The function of NK-lymphocytes was tested by lysis of the MOLT-4 cell line in a cytotoxicity assay, cytotoxicity index (CI). The functional ability of B- lymphocytes was indirectly estimated by the level of serum immunoglobulins classes IgM, IgA, IgG and circulating immune complexes (CICs). Phagocytic activity was determined as the amount of phagocytizing leukocytes (phagocytic number, $\mathrm{PhN}$ ) and as the mean number of bacterias Staphylococcus aureus absorbed by the phagocyte within 30 minutes of co-cultivation (phagocytic index, PhI). Total immune status was examined by 25 parameters. It was assessed before starting and after the end of therapy.

The immune status of patients was compared between two groups before and after therapy: in group 1 (46 patients), basis therapy was combined with reflexo-laser treatment, and in group 2 (50 patients), only basis therapy was performed.

\subsection{Methods of determining the efficacy of treatment}

Statistical analysis was performed using the Student's $t$-test. All data were presented as the Mean \pm SEM $(\mathrm{M} \pm \mathrm{m}) . \quad P<0.05$ was considered statistically significant. Analyses were performed using STATISTICA software (Version 8.o, StatSoft Inc., USA) [20]. Data on 70 practically healthy people served as control level (norm). 
Interquartile analysis was performed to identify the contribution of reflex-laser component to the change in the state of immunity when using it in combination with basic treatment. The data obtained were described using the interquartile intervals in the form of 1 and 4 quartiles (25 and 75 percentile). The number of immunological parameters, including both decreased (1 quartile) and increased (4 quartile) ones, was calculated in both groups of treatment (basis and basis+reflexo-laser). The average number of deviations was calculated for one examined patient. After the completion of treatment for radiation-induced injuries, deviation calculations were performed in a similar way.

\section{RESULTS AND DISCUSSION}

\subsection{The influence on the psycho-emotional sphere}

The applied restoration methods were found effective at correcting patients' psycho-emotional state. In 192 (80\%) of 240 patients, sleep was restored, depression and tearfulness disappeared or considerably diminished. The patients experienced an improvement in mood, became self-confident and wanted to continue the treatment (Figure 1).

$20 \%$

without effect

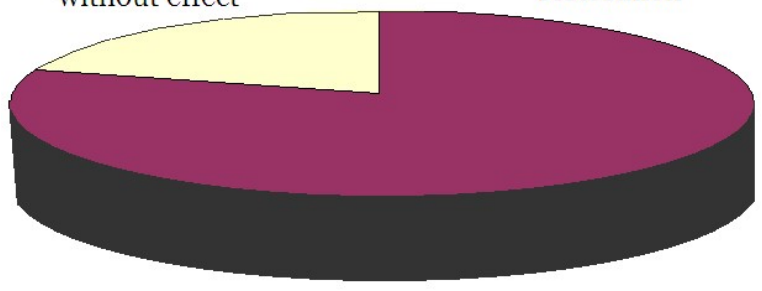

Figure 1. The effect of treatment for radiation-induced injuries on the emotional and psychic state of patients

The following results of treatment in pain syndrome were obtained: 156 (82\%) of 197 patients experienced considerable pain reduction, and in 68 of 79 patients with grade from 1 up to 4 pain, painful syndrome could be stopped. In 11 patients, pain was reduced up to the sensations that did not require parenteral administration of analgesia. Of 118 patients, in 47 (40\%) patients with grade from 4 to 8 , pains could be stopped, and in 59 (50\%) patients, pain intensity was reduced up to the sensations that did not require parenteral administration of analgesics and narcotics. In 12 cases (10\%), treatment failed to stop pain syndrome (the results are given in Table 1).

Table 1. Efficacy of medication therapy combined with reflexo-laser- therapy in relieving pain syndrome

\begin{tabular}{|c|c|c|c|c|}
\hline $\begin{array}{c}\text { Pain } \\
\text { Syndrome } \\
\text { grade) }\end{array}$ & $\begin{array}{c}\text { Number } \\
\text { of } \\
\text { patients }\end{array}$ & \multicolumn{3}{|c|}{ Efficacy of pain treatment, number, } \\
$\%$
\end{tabular}

These results were consistent with the data obtained by researchers who could reduce the level of lower back pain when reflexotherapy was included as an additional component of treatment $[21,22)$.

\subsection{Dynamics of neurological disorders}

After a course of restoration therapy, a positive dynamics was noted in 156 (65\%) cases of the total group of 240 patients with secondary neurological disorders. The patients had positive therapeutic changes such as increased range of motion and easing movements, reduced sensitivity disturbances (numbness, creeping sensation and "cold extremities").

It should be noted that sensitivity disturbances could be reduced or eliminated after 4-5 sessions. In order to reduce the motion disturbances, the full course of treatment (10-12 sessions) was required. In 84 (35\%) cases, there were slightly marked positive changes, or they were not seen at all. No health impairment and complications resulted from treatment. The advantage of the method is that it enables us to perform restoration therapy both in inpatient and outpatient treatment settings.

In stroke, because of ischemia or rupture of blood vessels, the blood supply to the brain was interrupted, which causes many health problems. The study of Hall P. (23) indicated that reflexotherapy as an alternative treatment improved recovery of neurological and physical changes in stroke patients.

\subsection{Assessment of the immune status}

In 96 patients with late radiation-induced injuries that were aggravated by a marked painful syndrome and torpid course the immune status was assessed before and after therapy of injuries. Data on the immune status of patients with late radiation-induced injuries aggravated by a marked pain syndrome and torpid course are given in Table 2.

Table 2. Immunity in patients with late radiation-induced injuries (see standard deviation sigma values except for the standard error of the mean)

\begin{tabular}{|c|c|c|}
\hline Index & $\begin{array}{c}\text { Radiation- } \\
\text { induced } \\
\text { injuries (total } \\
\text { group, before } \\
\text { therapy), } \mathrm{M} \pm \mathrm{m}\end{array}$ & $\begin{array}{l}\text { Healthy } \\
\text { people } \\
\text { (control } \\
\text { group), } \\
\mathrm{M} \pm \mathrm{m}\end{array}$ \\
\hline $\begin{array}{c}\text { Leucocytes, abs } 10^{9} \\
\text { cells/l }\end{array}$ & $5.43 \pm 0.21$ & $5.76 \pm 0.22$ \\
\hline $\begin{array}{l}\text { Lymphocytes, abs } 10^{9} \\
\text { cells/l }\end{array}$ & $1.80 \pm 0.08^{*}$ & $2.01 \pm 0.12$ \\
\hline Lymphocytes, \% & $34.3 \pm 1.05$ & $32.1 \pm 0.72$ \\
\hline \multicolumn{3}{|c|}{ T-lymphocytes } \\
\hline $\mathrm{CD}_{3+, \%}$ & $671 \pm 122$ & $71.6 \pm 2.2$ \\
\hline $\mathrm{CD}_{3}+$, abs $10^{9}$ cells/l & $1.20 \pm 0.06^{*}$ & $1.50 \pm 0.08$ \\
\hline $\mathrm{CD}_{4+, \%}$ & $37.7 \pm 1.11^{*}$ & $42.0 \pm 2.1$ \\
\hline $\mathrm{CD}_{4}+$, abs $10^{9}$ cells $/ \mathrm{l}$ & $0.64 \pm 0.03^{*}$ & $0.92 \pm 0.06$ \\
\hline $\mathrm{CD} 8+, \%$ & $27.7 \pm 0.98$ & $28.2 \pm 1.57$ \\
\hline CD8, abs & $0.49 \pm 0.03^{*}$ & $0.56 \pm 0.03$ \\
\hline CD4+/CD8+, IRI & $1.46 \pm 0.08^{*}$ & $1.84 \pm 0.10$ \\
\hline CD3+HLADR+, \% & $7.47 \pm 0.52^{*}$ & $5.60 \pm 0.30$ \\
\hline $\begin{array}{c}\mathrm{CD}_{3}+\mathrm{HLADR}+, \text { abs } 10^{9} \\
\text { cells } / 1\end{array}$ & $0.13 \pm 0.01$ & $0.12 \pm 0.01$ \\
\hline \multicolumn{3}{|c|}{ B- lymphocytes } \\
\hline CD 19+,\% & $10.8 \pm 0.68^{*}$ & $8.5 \pm 0.46$ \\
\hline CD 19+, abs & $0.19 \pm 0.01$ & $0.17 \pm 0.02$ \\
\hline IgM, g/l & $1.48 \pm 0.05$ & $1.52 \pm 0.07$ \\
\hline
\end{tabular}


E. Kuzmina et al., Late radiation-induced injuries in cancer patients..., RAP Conf. Proc., vol. 6, 2021, 121-127

\begin{tabular}{|c|c|c|}
\hline IgG, g/l & $13.91 \pm 0.25^{*}$ & $12.84 \pm 0.68$ \\
\hline IgA, g/l & $1.87 \pm 0.04$ & $1.96 \pm 0.06$ \\
\hline $\begin{array}{c}\text { CICs, optical density } \\
\text { units }\end{array}$ & $0.094 \pm 0.003$ & $0.09 \pm 0.004$ \\
\hline \multicolumn{3}{|c|}{ NK- lymphocytes } \\
\hline CD 16+,\% & $16.8 \pm 0.87$ & $18.7 \pm 1.40$ \\
\hline CD 16+, abs 109 cells/l & $0.29 \pm 0.02^{*}$ & $0.35 \pm 0.04$ \\
\hline CI 25:1 & $35.00 \pm 1.19^{*}$ & $40.2 \pm 2.29$ \\
\hline \multicolumn{2}{|c|}{ Phagocytes } \\
\hline Phagocytic number & $71.0 \pm 1.10^{*}$ & $65.0 \pm 0.68$ \\
\hline Phagocytic index & $5.30 \pm 0.13^{*}$ & $6.1 \pm 0.15$ \\
\hline Number of observations & 96 & 70 \\
\hline
\end{tabular}

* - differences are significant in comparison with control group ( $\mathrm{P}<0.05)$

Patients with developed radiation damages showed considerable immunological disturbances affecting the work of immune T-cell and NK-cell networks, phagocytes. In the whole, the decrease of individual parameters prevailed over their increase. On average, the number of circulating lymphocytes and T-cell populations for a group was reduced: total T-cells (CD3+), T-helper/inductors (CD4+) and cytotoxic Tlymphocytes (CD8+), IRI. A reduction in the number and function of $\mathrm{NK}$ cells $(\mathrm{CD} 16+, \mathrm{CI})$ was also observed. There were an increased number of phagocytizing cells and a decreased number of bacteria phagocytized by a phagocyte.

\subsection{Effect of restoration therapy on the immunity}

The immune status of patients was compared between two groups before and after therapy: in group 1 (46 patients), basis therapy was combined with reflexo-laser treatment, and in group 2 (50 patients), only basis therapy was performed.

The comparison did not reveal any significant differences in the initial immune status between these groups of patients with late radiation-induced damage (no data are presented).

After the completion of therapy, the immune status was repeatedly assessed in the same groups of patients. No significant differences in the immune status were noted after basis therapy combined with reflexo-laser treatment and after basis therapy alone.

The absence of group dynamics in processes being studied can be genuine or result from oppositely directed individual changes in parameters. When the value of the observed decrease in the immunity is close to its increase for the whole group, the mean parameters will not significantly vary.

To test a hypothesis about oppositely directed individual dynamic changes in immunity parameters, individual immunity parameters of patients were analyzed using two criteria: initial status and dynamics of immunity parameters during the treatment. Then, pre- and post-treatment values were compared. Depending on the initial status and changes in parameters during the treatment, three main subgroups were identified. Subgroup 1 comprised patients with a marked activation of nonspecific and specific immunity, i.e. with a higher initial lymphocyte count and most immune status parameters studied. In subgroup 2, a slight difference between the initial immune status and norm was noted. In subgroup 3, there were predominantly immunodepressed patients. The immune response to treatment in these subgroups was different. However, the outcomes appeared to be common both after basis therapy and after its combination with reflexo-laser acupuncture (Figure 2).

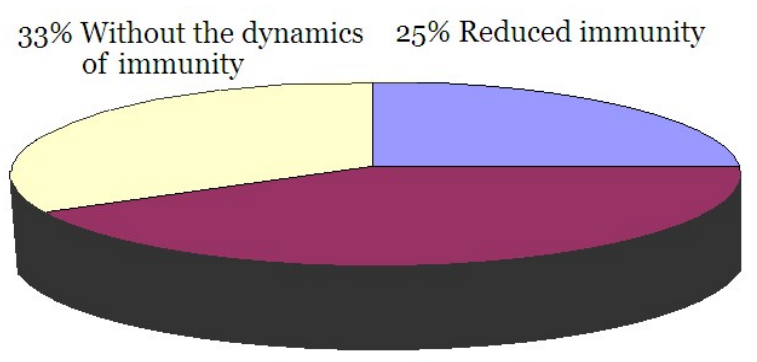

$42 \%$ Increase of immunity

Figure 2. Different effects of treatment on the immune response

In group 1, the treatment reduced hyperactivation. The initial immune status in patients of this group reflected the predominance of the active phase of the immune response to a viral and bacterial infection. It manifested inflammation and autoimmune processes as leukocytosis, lymphocytosis, increased number of cytotoxic lymphocytes and activated T-cells as well as intensified primary humoral immune response: a higher level of serum IgM class, increased phagocitic activity of phagocytes. Moreover, therapy resulted in a further reduction in the initially increased number of leucocytes, lymphocytes, and especially CD8+Tcytotoxic and activated (CD3+HLADR+) Tlymphocytes, B-lymphocytes, IgM level, CD16+NKcells, absorbing function of phagocytes. Interestingly, the levels of IgG, IgA, and CICs remained at optimum concentrations, and spontaneous cytotoxicity of NK cells considerably increased. It is noteworthy that the number of T-cells in both subpopulations decreased approximately to $80 \%$ of the normal level, and NKlymphocytes achieved a lower level.

In group 2, almost no significant changes occurred after treatment. Only the number of NK-cells increased a little, and spontaneous cytotoxicity in natural killers appeared to be slightly higher. The remaining parameters were kept at the initial level of $80-100 \%$ of norm.

In group 3, immunodepression was considerably reduced. The level of lymphocytes (number and percentage), T-cells and B-cells increased. Additionally, an intensified phagocytosis was seen, and there was a slight increase in the level of NK-cells. In the whole, initially reduced parameters were found to be increased up to 75-100\% of norm.

In the patients, who had received a course of basis therapy, similar subgroups and similar dynamics in treatment effects were identified (no data are presented because treatment results were similar).

Thus, the treatment including courses of basis therapy or its combination with reflexo-laser acupuncture had an immunomodulating effect, i.e. it reduced higher immune parameters and increased lower ones as close as possible to the normal value and did not significantly influence normal parameters.

It is a peculiarity of the immune status of patients with late radiation-induced injuries that in group 1 , treatment reduced the number of T-cells and NK-cells approximately to $80-95 \%$ of norm. In group 3, low 
numbers of circulating T- and NK-cells increased approximately up to the same level, and in group 2, they remained at the level of $80-95 \%$ of their numbers in practically healthy people. In our opinion, this difference between norm (practically healthy people) and patients who had received previous radiation therapy irrecoverable component of immunodeficiency of immune T-cell and NK-cell networks, i.e. conventional treatment methods fail to restore it. This component seems to reflect the results of postradiation immune aging processes, which suggests that the normal immune status of patients with radiationinduced injuries corresponds to the immune status of older healthy people.

\subsection{Effect of reflexo-laser therapy}

To determine the contribution of reflexotherapy to the efficiency of the restoration of the immune status, the extent of immunomodulation was calculated for every immune parameters. To do this, the data obtained were described using interquartile intervals in the form of 1 and 4 quartiles (25 and 75 percentiles) The number of immunological parameters including both decreased (1 quartile) and increased (4 quartile) ones, was calculated in both treatment groups (basis and basis+reflexo-laser). The average number of deviations was calculated for one examined patient. After the end of radiation injuries treatment, deviation calculations were performed in a similar way. The restoration of immunity for two types of treatment (basis therapy and its combination with reflexo-laser treatment) was shown (Table 3).

Table 3. Immunomodulatory effect of basis therapy and its combination with reflexo-laser therapy

\begin{tabular}{|l|c|c|c|c|}
\hline \multirow{2}{*}{} & \multicolumn{3}{|c|}{ Immunomodulatory effect } \\
\cline { 2 - 5 } & \multicolumn{2}{|c|}{ Basis therapy } & \multicolumn{2}{c|}{$\begin{array}{c}\text { Basis therapy + } \\
\text { reflexo-laser } \\
\text { therapy }\end{array}$} \\
\hline $\begin{array}{l}\text { The average } \\
\text { number of } \\
\text { parameters } \\
\text { deviating from } \\
\text { norm for one } \\
\text { patient, M } \pm \mathrm{m}\end{array}$ & $\begin{array}{c}\text { Before } \\
\text { therapy }\end{array}$ & $\begin{array}{c}\text { After } \\
\text { therapy }\end{array}$ & $\begin{array}{c}\text { Before } \\
\text { therapy }\end{array}$ & $\begin{array}{c}\text { After } \\
\text { therapy }\end{array}$ \\
\cline { 2 - 5 } $\begin{array}{l}\text { Degree of } \\
\text { restoration, } \\
\text { normalized } \\
\text { parameters of } \\
\text { immunity } \\
\text { following } \\
\text { therapy M } \pm \mathrm{m}, \\
\%\end{array}$ & $3.94 \pm 0$. & $\begin{array}{c}6.46 \pm 0 \\
\text { \% }\end{array}$ & $\begin{array}{c}3.12 \pm \\
0.30^{*} \\
* *\end{array}$ \\
\hline
\end{tabular}

* - differences are significant in comparison with the pre-treatment state in the same group $(\mathrm{P}<0.05)$

** - differences are significant in comparison with basis therapy $(\mathrm{P}<0.05)$.

The presented data demonstrate that the mean value of increase and decrease parameters for one patient was considerably dropped following basis therapy, as well as following combination treatment including acupuncture. However, the degree of restoration after therapy combined with reflexo-laser treatment was found to be higher $(51.5+5.3 \%)$ than after basis therapy alone $(38.2+4.9 \%)$. The differences are statistically significant $(\mathrm{P}<0.05)$.

Thus, in group of patients, who received conventional therapy without reflexo-laser treatment, the immunomodulatory effect occurred. However, the degree of the immunomodulatory effect was slightly lower than that after basis therapy plus reflexo-laser therapy. The obtained results suggest that the mechanisms of the effect of reflexo-laser therapy on the immunity do not completely coincide with action of components of drug treatment, which improves its efficacy. Therefore, the introduction of reflexo-laser treatment in the conventional program of therapy for late radiation injuries is advisable to improve the quality of life in patients and normalize the immunity.

In the scientific literature, we found several studies showing that the impact of acute stroke, viral infections and stress tended to become normal due to the inclusion of immunocorrecting and immunomodulating mechanisms with the help of acupuncture and laser therapy [23]-[25].

Modern ideas about the mechanisms of acupuncture identify the peripheral [7]-[9], segmental [9]-[11] and central level [12]-[16] effects. The neuroamine link connects the immune, nervous and endocrine systems that coordinate work, supports homeostasis and vital activity of the body [4].

Radiation injury therapy using medical treatment with vascular, anti-inflammatory, analgesic and narcotic drugs with the addition of reflexotherapy generally affects the patient's health, improving the physical, emotional and spiritual state.

\section{CONCLUSION}

Study design of therapy for radiation-induced injuries developed and implemented at MRRC represents a single-center, single-stage, cohort, open, controlled study. The retrospective analysis evaluated the data of patients with radiation injuries that occurred over the long term after cancer treatment.

Therapy performed with the use of pharmacological agents (analgetics, neuroleptics and narcotics), socalled basis therapy, in combination with reflexo-laser therapy considerably reduced psycho-emotional and pain symptoms of late radiation-induced injuries. The analgesic effect is achieved after the first 3-5 sessions of therapy including reflexo-laser treatment. As a result, the use of analgesics and narcotics can be reduced. This therapy improves the quality of life for patients: they can attend to themselves and add more physical activity to their life.

The effects of basis therapy alone and in combination with reflex treatment on immunity were compared. Basis therapy has an immunotrope modulating effect. It restores adaptation mechanisms while reducing immune hyperactivation and immunodepression. By adding reflexo-laser treatment, basis therapy appeared to be more successful restoring immunological disorders. The treatment reduced pain; helped the body to maintain the dexterity and locomotion ability; improved general sense of relaxation especially overused hands, feet, and the whole body parts; stimulated the release of body's pain-relieving chemicals; promoted recovery process from any injury at any region.

Understanding the mechanisms of basic and acupuncture treatment enabled using a combination of these methods for the treatment of a wide range of 
pathological conditions, including pain syndromes, autonomic nervous system dysfunction, sleep disorders, emotional disorders and immune imbalance.

Therefore, the use of reflexotherapy in the conventional treatment should be recommended not only for patients with late radiation injuries but also for other pathological conditions to enable the recovery and improve the quality of life for patients.

\section{REFERENCES}

1. M. S. Bardychev, S. N. Katsalap, "Local radiation damage: the characteristics of its pathogenesis, diagnosis and treatment", Vopr. Onkol., vol. 41, no. 2 , p. 99,1995 PMid: 7483460

2. Е.А. Ростачева, "Влияние рефлексотерапии на противовирусный иммунитет”, Детская медицина северо-запада, т. 8, но. 1, с. 289 - 290, 2020.

(E. A. Rostacheva, "The influence of reflexology on antiviral immunity", Child. Med. North-West, vol. 8, no. 1, pp. 289 - 290, 2020.)

Retrieved from:

https://elibrary.ru/item.asp?id=46338577

Retrieved on: May 10, 2021

3. G. O. Andreeva, K. M. Naumov, "Modern concepts of acupuncture mechanisms", Russian Military Med. Acad. Rep., vol. 39, no. s3 - 5, pp. 11 - 13, 2020.

4. А. М. Василенко, С. А. Радзиевский, Л. Г. Агасаров, С. А. Бугаев, "Рефлексотерапия в формате восстановительной медицины”, Вопросы курортологии, физиотерапии и лечебной физической культуры, т. 90, но. 1, с. 32 - 38, 2013.

(A. M. Vasilenko, S. A. Radzievsky, L. G. Agasarov, S. A. Bugaev, "Reflexotherapy in the context of rehabilitative medicine", Questions of balneology, physiotherapy and therapeutic physical culture, vol. 90 , no. 1, pp. $32-38$, 2013.)

Retrieved from:

https://www.mediasphera.ru/issues/voprosykurortologii-fizioterapii-i-lechebnoj-fizicheskojkultury/2013/1/030042-8787201316 Retrieved on: May 10, 2021

5. Е.Г. Кузьмина и другие, “Интегративная (рефлексолазерная) терапия в восстановлении онкологических больных после комбинированной терапии (клинико-иммунологические аспекты)”, в кн. тез. 3-й Международный форум “Интегративная медицина 2008," Москва, Россия, 2008, c. $147-151$.

(E. G. Kuzmina et al., "Integrative (reflexo-laser) therapy in restoration of oncologic patients after combination therapy (clinical-and-immunologic aspects)", in Book of Abstr. $3^{\text {rd }}$ Int. Forum "Integrative medicine 2008," Moscow, Russia, 2008, pp. 147 - 151.)

6. Е.А. Гурьянова, "Место рефлексотерапии в системе медицинской реабилитации", в кн. тез. Межрегиональной научно-практической конференции Вопросы Медицинской Реабилитации, Чебоксары, Россия, 2018, с. 26 - 32. (E. A. Guryanova, "The place of reflexology in the system medical rehabilitation", in Book of Abstr. Conf. Issues of medical rehabilitation, Chuvashiya, Russia, 2018, pp. $26-32$.)

7. A. Uncini et al., "Effect of closely repeated cathodal transcranial direct current stimulations", Clin. Neurophysiol., vol. 128, no. 3, p. e150, Mar. 2017. DOI: $10.1016 /$ j.clinph.2016.10.395

8. M. C. Ridding, U. Ziemann, "Determinants of the induction of cortical plasticity by non-invasive brain stimulation in healthy subjects", J. Physiol., vol. 588, no. 13, pp. 2291 - 2304, Jul. 2010. DOI: 10.1113/jphysiol.2010.190314
PMid: 20478978

PMCid: PMC2915507

9. M. Vitor-Costa et al., "Improving cycling performance: transcranial direct current stimulation increases time to exhaustion in cycling", PLOS ONE, vol. 10, no. 12, e0144916, Dec. 2015.

DOI: 10.1371/journal.pone.0144916

PMid: 26674200

PMCid: PMC4687680

10. J. Nelson et al., "The effects of transcranial direct current stimulation (tDCS) on multitasking throughput capacity", Front. Hum. Neurosci., vol. 10, 589, Nov. 2016.

DOI: 10.3389/fnhum.2016.00589

PMid: 27965553

PMCid: PMC5126079

11. E. Santarnecchi et al., "Enhancing cognition using transcranial electrical stimulation", Curr. Opin. Behav. Sci., vol. 4, pp. 171 - 178, Aug. 2015. DOI: 10.1016/j.cobeha.2015.06.003

12. S. Reardon, "'Brain doping' may improve athletes' performance", Nature, vol. 531, no. 7594, pp. 283 - 284, Mar. 2016.

DOI: 10.1038/nature.2016.19534

PMid: 26983516

13. R. A. McKinley, L. McIntire, J. Nelson, J. Nelson, C. Goodyear, "The effects of Transcranial Direct Current Stimulation (tDCS) on training during a complex procedural task", in Advances in Neuroergonomics and Cognitive Engineering, vol. 488, K. S. Hale, K. M. Stanney, Eds., 1st ed., Cham, Switzerland: Springer, 2017, pp. $173-183$.

Retrieved from:

http://library.lol/main/48FCD7Co78F18C6FED67990 73A8E25Co

Retrieved on: Jan. 12, 2021

14. C. Lustenberger, M. R. Boyle, A. A. Foulser, J. M. Mellin, F. Fröhlich, "Functional role of frontal alpha oscillations in creativity", Cortex, vol. 67, pp. 74 - 82, Jun. 2015.

DOI: 10.1016/j.cortex.2015.03.012

PMid: 25913062

PMCid: PMC4451406

15. A. Vossen, J. Gross, G. Thut, "Alpha power increase after transcranial alternating current stimulation at alpha frequency ( $\alpha$-tACS) reflects plastic changes rather than entrainment", Brain Stimul., vol. 8, no. 3, pp. 499 - 508, May-Jun. 2015.

DOI: $10.1016 /$ j.brs.2014.12.004

PMid: 25648377

PMCid: PMC4464304

16. J. Yu, T. Yu, J. Han, "Aging-related changes in the transcriptional profile of cerebrum in senescenceaccelerated mouse (SAMP10) is remarkably retarded by acupuncture", Acupunct. Electrother. Res., vol. 30, no. 1 - 2, pp. 27 - 42, 2005.

DOI: $10.3727 / 036012905815901370$ PMid: 16231630

17. P. Karoly, M. P. Jensen, Multimethod assessment of chronic pain, Oxford, UK: Pergamon, 1987, p. 172.

18. Д.Д. Бернс, При панических атаках: новая безлекарственная тревожная терапия, которая может изменить вашу жизнь, Москва, Россия: Издательство Альпина, 2021, c. 550.

(D. D. Burns, When panic attacks: the new, drug-free anxiety therapy that can change your life, Moscow, Russia: Alpina Publisher, 2021, p. 550.)

19. N. H. Embong, Y.C. Soh, L. C. Ming, T. W. Wong, "Revisiting reflexology: Concept, evidence, current practice, and practitioner training," J. Tradit. Complement. Med., vol. 5, no. 4, pp. 197 - 206, Oct. 2015.

DOI: 10.1016/j.jtcme.2015.08.008

PMid: 26587391

PMCid: PMC4624523 
20. S. A. Glantz, Primer of Biostatistics, 7th ed., New York (NY), USA: McGraw-Hill, 2012.

Retrieved from:

https://accessanesthesiology.mhmedical.com/book.asp $\mathrm{x}$ ?bookid $=665$ \&isMissingChapter $=$ true

Retrieved on: Aug. 15, 2021

21. F. Quinn, C. M. Hughes, G. D. Baxter, "Reflexology in the management of low back pain: a pilot randomised controlled trial," Complement. Ther. Med., vol. 16, no. 1 , pp. $3-8$, Feb. 2008.

DOI: 10.1016/j.ctim.2007.05.001

PMid: 18346622

22. C. K. Chen, A. J. Nizar, "Myofascial pain syndrome in chronic back pain patients," Korean J. Pain, vol. 24, no. 2, pp. $100-104$, Jun. 2011.

DOI: 10.3344/kjp.2011.24.2.100

PMid: 21716607

PMCid: PMC3111556
23. P. Hall, "Reflexology for Stroke," Positive health, Oct. 2002.

Retrieved from:

http://www.positivehealth.com/article/reflexology/refl exology-for-stroke

Retrieved on: Aug. 15, 2021

24. H. J. Baltrusch, W. Stangel, I. Titze, "Stress, cancer and immunity. New developments in biopsychosocial and psychoneuroimmunologic research," Acta Neurol., vol. 13, no. 4, pp. 315 - 327, Aug. 1991.

PMid: 1781308

25. N. M. Burduli, L. G. Ranyuk, "The influence of laser radiation on the functional activity of leucocytes, lipid peroxidation and antioxidant defensein patients with chronic acalculous cholecystitys", Kuban Scientific Medical Bulletin, vol. 140, no. 5, p. 56, Krasnodar, Russia, 2013. 